\title{
Material Responses to the Great Depression in Northeast England
}

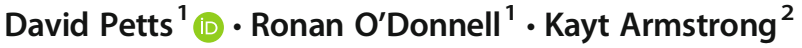

Accepted: 1 February 2021 / Published online: 28 April 2021

(C) The Author(s) 2021

\begin{abstract}
The Great Depression of the 1920s and 1930s was a global economic crisis, yet to understand its impacts in material terms, it is necessary to recognize that they were situated within specific local and regional contexts. This article, drawing on the work of the Leverhulme Trust-funded Landscapes of the Great Depression in the North East project, explores the impacts and responses to the Great Depression in Northeast England through an exploration of the materiality of a series of different responses to the crisis, as well as wider consideration of its impact on the landscape. By moving beyond an individual site, and instead looking at a range of interventions at site and landscape scale it shows the potential of taking a more holistic and comparative approach to exploring the impact of the Great Depression and offers an approach that might be used to better understand economic crises in other situations and contexts.
\end{abstract}

Keywords landscape $\cdot$ Britain $\cdot$ Depression $\cdot$ Economy $\cdot$ Settlement

\section{Introduction}

The interwar period (1918-39) was one of extraordinary change. Out of the ashes of World War I grew an increase in consumerism, which from the late 1920s was paradoxically played out alongside the Great Depression. Extreme politics flourished, and authoritarian regimes became established in Spain, Italy, Russia, and Germany. The tensions between these new state formations and traditional polities resulted in re armament and ultimately conflict. Simultaneously, the foundations of the post-War settlement, welfare states and European style social democracies were being

David Petts

d.a.petts@durham.ac.uk

1 Department of Archaeology, Durham University, Durham DH1 3LE, UK

2 Magnitude Surveys, 17-19 Commerce Ct, Challenge Way, Bradford BD4 8NW, UK 
laid (Harrison 2009). These social, economic, and political developments all resulted in material developments that can be interrogated archaeologically.

In particular, the Great Depression was arguably the first crisis in "modernity," and a truly global articulation of economic and social disruption. As well as the immediate impact of unemployment and inflation, it also led to a crisis of confidence that capitalism (and the notion of economic growth) was constant, self-correcting and required little in terms of intervention to keep it functioning (Hobsbawm 1994: 8788). The Depression acted as a key bridging phenomenon that linked the ultimately unsuccessful attempts to reach a satisfactory political and economic new beginning following the Great War with the emergence of new global socio political structures that resulted in the "hot war" of 1939-45 and the subsequent Cold War which ended in the late 1980s. This article explores the initial results of a major research project that attempted to explore the Great Depression in one corner of the United Kingdom through an avowedly material lens. In particular, it explores how an international event may be examined through the spatially situated (site, settlement, landscape) approach that archaeology assumes. It was this underlying problematic that was taken as the point of departure for the Landscapes of the Great Depression project funded by the Leverhulme Trust and carried out by the authors at Durham University (UK).

\section{Northeast England in the Great Depression}

The northeast of England (the historic counties of County Durham and Northumberland, now Teesside, County Durham, Tyne and Wear, and Northumberland) was a region which was economically dominated by heavy, extractive industry. Coal mining was particularly significant, both economically and socially, but ironstone mining was important in the south of the region in Cleveland. Steelmaking was important on Teesside and in County Durham, while there were significant shipbuilding industries on the major rivers (Tyne, Tees, and Wear). More modern industries, including chemical manufacture and light engineering were also becoming increasingly important. The interwar depression hit the Northeast particularly intensively due to its dependence on these heavy industries (Stevenson and Cook 1977). However, despite a brief boom following World War I, the Depression took place against a longer-term backdrop of declining industrial activity since the late nineteenth century. The mid1920s had been a particularly hard time for the coal industry with British exports being badly affected by the 1925 return to the Gold Standard and the re entry of Germany to the international coal market. The dependency on heavy industry also meant that the impact of the Depression was felt longer, with the recovery from 1933 felt much more slowly. As a region, northeast England suffered the highest unemployment rates in Britain - unemployment rates peaked at $28.5 \%$ in 1932 , with significantly higher rates found in many localities (Garside 1990: 10). In the ironstone mining areas of Cleveland, at one point adult male unemployment levels reached 90\% (Chase 2010). The "Jarrow Crusade," a march of unemployed shipyard workers of $290 \mathrm{mi}(467 \mathrm{~km})$ from Jarrow to London which took place in October 1936 became one of the most iconic images of the Great Depression in Britain - here unemployment rates reached over $70 \%$. Despite the significance of industry in the region, it is important to appreciate that agriculture remained prominent throughout. Hill sheep farming dominated upland areas 
in the west and north of the region, but lowland arable farming was also widespread (Stamp and Temple 1941). Nonetheless the economic significance of agriculture was muted by the long depression that the industry had been suffering nationally since the 1870s (Howkins 1991). The distinct settlement pattern of small mining villages that grew up around pitheads meant that islands of industrial stress and unemployment were often surrounded by large tracts of agricultural land (Sill 1982).

Unlike in the US, the British government did not undertake a broad-scale intervention to alleviate the effects of unemployment, inflation, and social dislocation akin to the "New Deal" (Patel 2016; Smith 2014). Many of the initial responses in Britain were essentially voluntarist in nature, even though the principal of central government involvement in training had been sanctioned since the Empire Settlement Act of 1922 (Field 2013: 99). Instead, the response was focused regionally on a small number of areas where the challenges were particularly acute. Thus, the northeast of England was designated a "Special Area" in the Special Areas Act (1934) (amended 1937 Special Areas (Amendment) Act (1937)), which gave a commissioner funds to invest in structural developments to ameliorate the impact of unemployment and stimulate economic investment in the region (Page 1976; Special Areas Commission 1935, 1937, 1938) (Fig. 1). The case studies presented below were carefully selected to embrace a range of projects that straddled this dichotomy of governmental and voluntary intervention

\section{Framing the Study of the Great Depression}

The study of the archaeology of the twentieth and twenty-first centuries has emerged as a distinctive sub discipline within archaeology (Bradley et al. 2004; Buchli and Lucas 2001; Dawdy 2006; González-Ruibal , 2019; Saitta 2007). In Britain the focus has been on the second half of the twentieth century, with a particular interest in the material dimension of post/super/hyper modernity (Harrison and Schofield 2010). Archaeological approaches to the interwar period (1918-39), particularly in Britain, have been more limited, perhaps seen as too recent for those working on the broader postmedieval world, and not recent enough for those engaging in a distinctive tradition of contemporary archaeology. Attempts to engage with the archaeology and materiality of the Great Depression have been particularly noticeable by their absence (although see Anonymous 2013; Barker and Lamb 2009; Libbon 2012; Smith 2001; Stewart et al. 2020; Tuck 2011; Wurst and Ridarsky 2014), with the work that has been done in a CRM context largely remaining in the realms of "gray literature" (e.g., Daniels 2010).

The aim of the Landscapes of the Great Depression project funded by the Leverhulme Trust was to take an avowedly material approach to the impact of the Depression in Northeast England. While, the impact of the crisis is usually explored in terms of financial and employment statistics, or oral historical reminiscences of hard times (e.g., Gray 2017), this project took the position that both the economic problems and the responses to them resulted in material interventions onto the built environment. By focusing on the complex relationship between human action, space, and built or material environments, archaeology is well placed to frame the study of the Depression. In particular, by working at a range of scales, it is possible to coalesce broader patterns from often small-scale data points. 


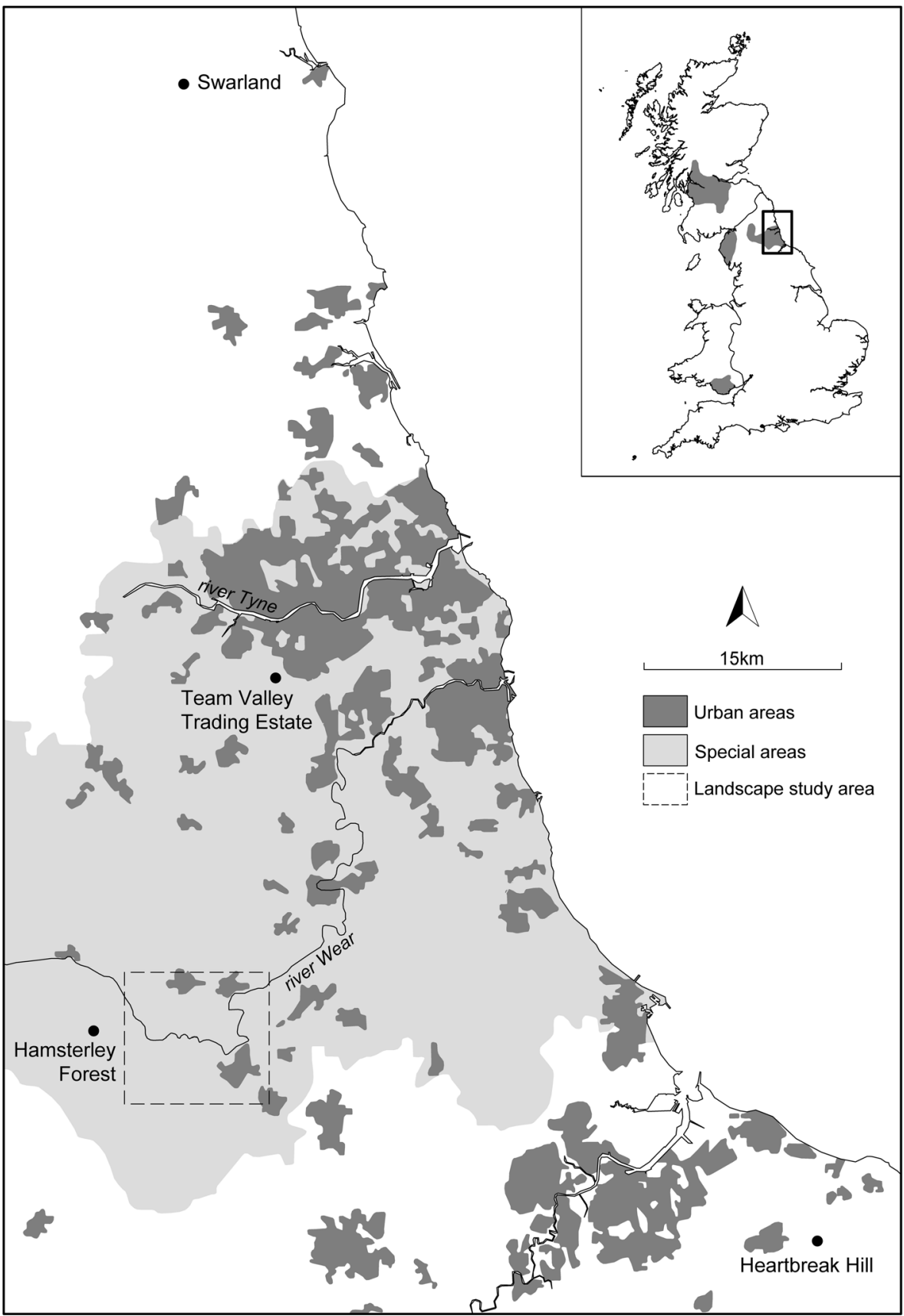

Fig 1 A map showing the locations of the four case studies and the Special Areas designated by the 1934 Act. (C) Durham University

A second key starting position for this work was that the study of the Great Depression is an archaeological intervention into the study of capitalism itself (for archaeological perspectives on capitalism see Johnson 1996; Orser 1996; Leone 1995; 
Lewis 2016; Matthews 2012; Wurst 2015). Taking capitalism as defined as a system (mode of production) combining production, distribution, and consumption of surplus value, this archaeological approach can be unpacked as acknowledging some key perspectives (cf., Lewis 2016; Wolf 1999: 73-100). First, that capitalism is a dynamic process which plays itself out through periodic or cyclical crises. While the Depression might have been one of the most dramatic and extensive of such crises, it was not the first and will not be the last. It was not a unique event; it was distinctive in its extent but not in its underlying nature. A second key perspective underpinning the work of the project was the acknowledgment that capitalism is played out spatially - the logic of capitalism relied on the production, circulation, and consumption of social surplus that takes place within a spatialized framework (e.g., Harvey 2001). The corollary of this is that shifts in capitalism have distinct spatial consequences that can be mapped and explored, and that attempts to restructure or respond to crises in capitalism will themselves have their own spatial underpinnings (cf., Lewis 2016). Crucially, the spatial dimensions of capitalism and its crises are uneven; these impacts are felt less strongly in some areas, while coalescing and clotting in others (cf., Potter, 1999: 68-9; Purser 1999: 117; Wurst and Ridarsky 2014). Here, the issue of scale is also fundamental - local trends and tendencies can be identified often countering wider regional patterns. In his analysis of space and capital David Harvey (1990) outlined three modes in which space might unfold - built environment, by which he meant the physical material world, representations of space cultural abstractions and representations of such spaces and spaces of representation, which are ideas and visions of spaces that could be (Harvey 1990: 218-225). Inevitably, these are heuristic devices, which overlap. The built environment might be constructed to be viewed from a distance or use particular types of architectural idiom which are mapped and photographed as representations of ideal or model types of site or structure. Equally, idealized or model settlements themselves contain within them the ambition or dream of a potential future that might be should the necessary material and social conditions be in place. This has methodological implications emphasizing the importance of understanding these impacts at different scales and bringing overlapping discourses to the fore to encouraging a comparative perspective that allows different trajectories of crisis and response to be identified and avoiding writing the story of the Great Depression through just one optic.

The project took a twofold approach - exploring both individual sites and wider landscapes. It located a series of sites where there were particular programs of physical construction or reworking of space underpinned by a variety of structural and financial organizations. It rapidly became clear that these sites were often where this reworking of space went hand in hand with interventions on the health and physicality of the individuals who populated these spaces through programs of "bodywork." As well as individual bounded sites, a wider landscape frame was also developed that was capable of moving beyond site specific interventions and identifying wider ranging but often small-scale and incremental change.

\section{Landscape}

Detailed case studies of specific interventions are important in developing a picture of the spatial and material relationships articulated and stimulated by the Depression. 
However, they offer only micro scaled analyses of pro active initiatives that engage with crisis. A wider aim of the Landscapes of the Great Depression project was to delineate how the Depression led to landscape-scale changes, both through processes of desertion, ruin, and decline as well as construction and evolution. It was clear from the very beginning that not all reactions to the changing economy took place at a corporate or organizational level; the impact might also be explored at the level of actions by individuals or families. Equally, even where changes were being stimulated by a higher level of intervention, these effects were not necessarily concentrated at specific sites of intense activity such as work camps or land settlement schemes, but could also be more widely dispersed through small-scale, intensely localized actions.

These processes were explored through a landscape scale analysis of a $10 \mathrm{~km} \mathrm{x}$ $10 \mathrm{~km}$ block of land in central County Durham centered on the market town of Bishop Auckland in the middle Wear valley. Underpinned by the development of a GIS database, this work aimed to ask what changed (use; extent; presence/absence), where the changes were (buildings; property plots/parcels; transport routes; utilities) and when these changes occurred (how fast? One off events or cumulative processes?). Mapping such changes over a relatively fine chronological period (less than a decade) of course presented practical methodological issues. Traditional map regression approaches usually work with wider chronologies; a particular issue was trying to distinguish changes in the 1930 s caused by the Depression from the major phase of landscape transformation initiated by World War II and its immediate run up in the late 1930s. Nonetheless, a series of potentially useful sources were identified. Helpfully, official mapping in the form of Ordnance Survey maps bracketed our study period with revisions in 1924-26 and 1939 (although in the process of analysis some queries about how much of the official "1939" survey actually took place a little later emerged). Sir Dudley Stamp's innovative land utilization survey published in 1934 also provided additional background context (Stamp and Temple 1934), while a range of complex archival datasets with spatial components were identified, including local municipal planning applications for construction, mine employment and output records and rate valuations, supplemented by local newspaper reporting. Together this allowed the creation of a detailed, textured mapping and analysis of the changing landscape of Bishop Auckland and its hinterland across most of the 1930s.

\section{Bishop Auckland in its Landscape}

Bishop Auckland lies on the River Wear with the smaller towns of Willington and Crook to its north and northwest. Sitting on the edge of the Magnesian limestone associated with the coal measures in County Durham, the eastern half of our study area was characterized by a landscape of coalmines, pit villages, and spoil heaps, in contrast to the less industrialized western section (Hewitt 2011). The town saw substantial population increase over the nineteenth century due to the rise of the coal industry as well as associated iron working. It also became important as a railway node which saw coal, lime, ironstone, and other mineral wealth from the North Pennines moving through the town towards coastal consumers and the main East Coast rail line. Despite the dominance of coal as a source of employment, unemployment rates were already growing from 1915, as coal reserves became diminished. By $1929,27 \%$ of the workforce was jobless, a figure that rose to $60 \%$ in 1932, although this had reduced to a still substantial 36\% by 1937 (Bulmer 1978: 145). 
These headline figures of unemployment exacerbated by the Depression, but underpinned by a longer-term decline in the colliery industry, might lead one to anticipate an entirely negative narrative of decline. As might be expected, planning applications were initially low, bottoming out in 1931, but recovering in line with wider national and international recovery toward the mid-1930s (Fig. 2a). However, unpicking this data, it is noticeable that throughout the Depression the most common type of property being built was new housing (Fig. 2b). This was particularly in the form of suburban semi-detached properties (47\% of identifiable new planning applications) rather than the traditional terraced housing commonly associated with industrial workforces in the region (cf., Olechnowicz 1997). "Villas" (a term poorly defined in the documentary sources) and bungalows comprised another $14 \%$ of the new housing constructed. Unlike terraced housing, which usually had external washing and lavatory facilities, these new buildings were provided with internal bathrooms and toilets, indicating an increasing concern with cleanliness and domestic hygiene. Most of the new houses were being constructed in small groups of usually no more than ten, usually by speculative developers. Government subsidy also allowed some non profit developers to build larger areas of housing; the construction of 48 semi-detached houses at Ashcroft Gardens, Bishop Auckland by the North-Eastern Housing Association is not untypical of the kind of new landscape of "suburban" housing going up in the later 1930s (Fig. 3) (Special Areas Commission 1938: 144; Malpass and Jones 1996). While the requirement for internal bathrooms might have been a condition of planning permission at local governmental level, it is clear that any additional costs incurred were not putting developers off constructing new housing stock, and the level of house construction seems to have remained buoyant throughout the Depression. The planning applications also demonstrated the impact of increased car ownership; $9 \%$ of all planning applications were for new garages. While terminologically it was not always easy to distinguish which of these were for domestic garages and which were for commercial petrol stations, it was nonetheless indicative of the presence of a section of the population purchasing cars for domestic use.

Within Bishop Auckland, and to a lesser extent, Crook and Willington, it is clear that despite the economic crisis, there remained pockets of increasing prosperity, with the emergence of new suburbs housing a relatively economically successful middle class, keen to have access to the latest modern conveniences including internal bathing facilities and cars. This is a salutary reminder that while the overall impact of the Depression was negative, for those that remained in employment, the decrease in cost of consumer goods, allowed an increasingly aspirational sector of society to access material markers of status, as well as increasing expectations in what was appropriate in terms of hygiene and respectability.

Nonetheless, the impact of the depression of was very real in and around Bishop Auckland. Evidence of more formal governmental intervention was also visible. The South-West Durham Improvement Association (SWDIA) incorporated in 1937 and funded through the Special Areas Act had a policy of active intervention on the landscape, while a program of land settlements was enacted directly by Durham County Council. The SWDIA leased land to the same company that ran the Team Valley Industrial Estate (see below) and who were responsible for the construction of a group of factories for light engineering on the outskirts of Bishop Auckland constructed in 1937 (Loebl 1978: 7, 1988). These reflected a wider impulse to realign the economy 
a

Planning Applications Jan 1929 - Mar 1937

200

180

160

140

120

100

80

60

40

20

0

1929

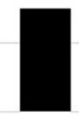

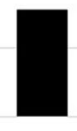

1930

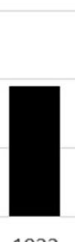

1932
1933

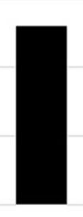

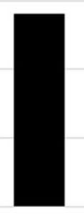

1934

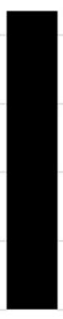

1935

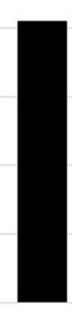

1936

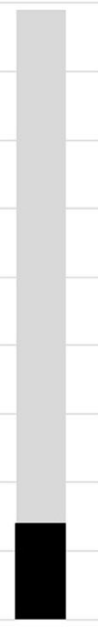

1937

b

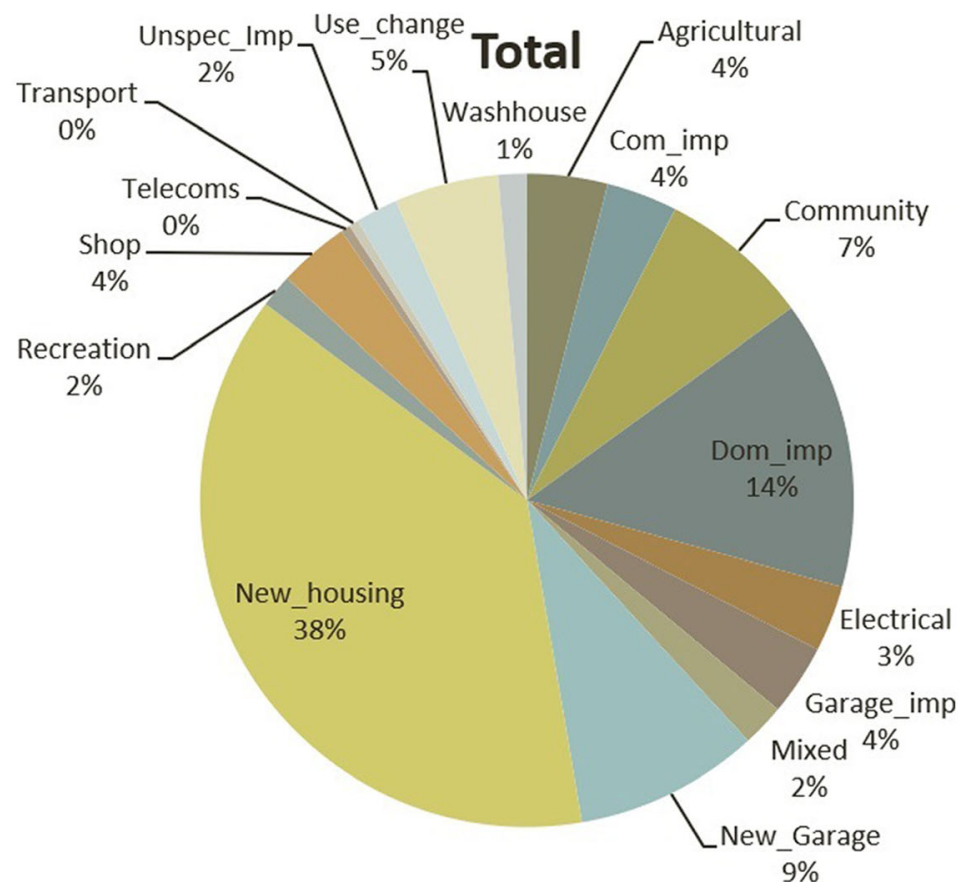

Fig. 2 a Graph showing changing rate of planning applications in the study areas during the early 1930s. Figures for 1937 were only recorded up to March. Grayed out box indicated projected totals based on first four months applications. b Graph of planning applications showing range of new building in the study area during the early $1930 \mathrm{~s}$ 

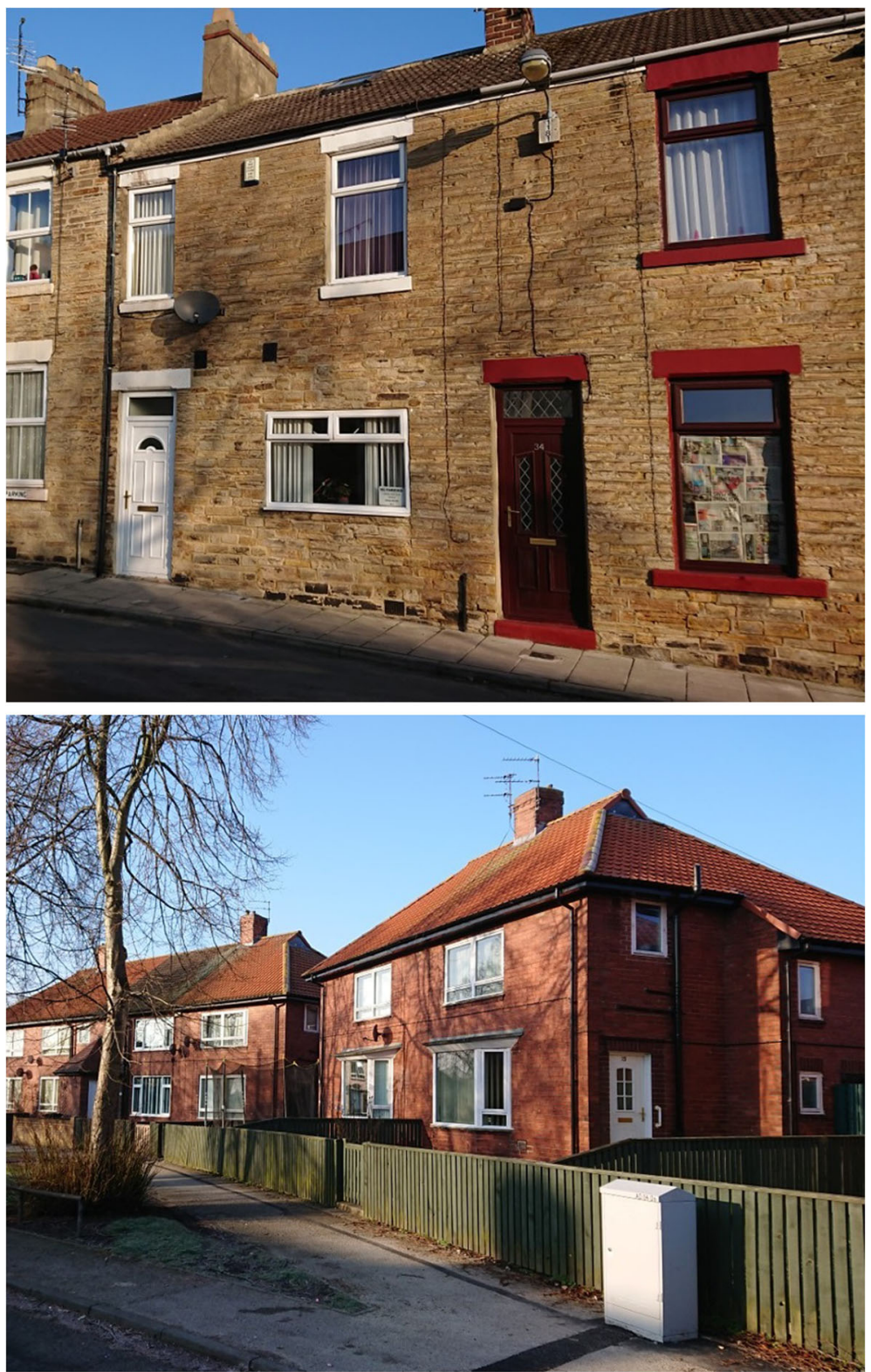

Fig. 3 Housing in Bishop Auckland: Traditional "two-up; two-down" workers housing, late nineteenth century; typical 1930s semi-detached housing built by the Northeastern Housing Association: Ashcroft Gardens, Bishop Auckland. Photograph by David Petts

away from heavy, extractive industries and toward lighter engineering and production of consumer goods. These new factories included premises for manufacturing plastic mouldings, clothing, handbags and other leather goods, buttons, buckles, and dress ornaments. Many of the new tenants of these commercial premises were existing concerns, often run by refugees from Germany and Eastern Europe. The subsidies 
available via the Special Areas Acts actively incentivized these kind of light engineering and production companies to move into the area, as the costs of expansion in the south of England, where the impacts of the Depression had been less extreme and ended earlier, were too expensive. Crucially, some of these new commercial concerns brought workforces from outside the area into the town and provided them with housing (Loebl 1978: 186). This is a clear case of how the demand for consumer goods and their associated production lead directly to the development of a new landscape of housing in the town replacing traditional industrial housing. These new concerns not only increasingly offered employment for women but lead to a wider reworking of the landscape. Their construction saw the roads in the immediate area reworked and sharp corners smoothed to allow easier access to the factories by heavy commercial vehicles. A good example of this occurred at the village of St Helen's Auckland, to the southwest of Bishop Auckland. The settlement had a medieval street plan with the main route through the village taking two right-angle turns to bring it around the nucleus of the manor house and the neighboring parish church. However, the early 1930s saw the construction of a series of new factory units on land to the east of the village. The increased vehicle traffic
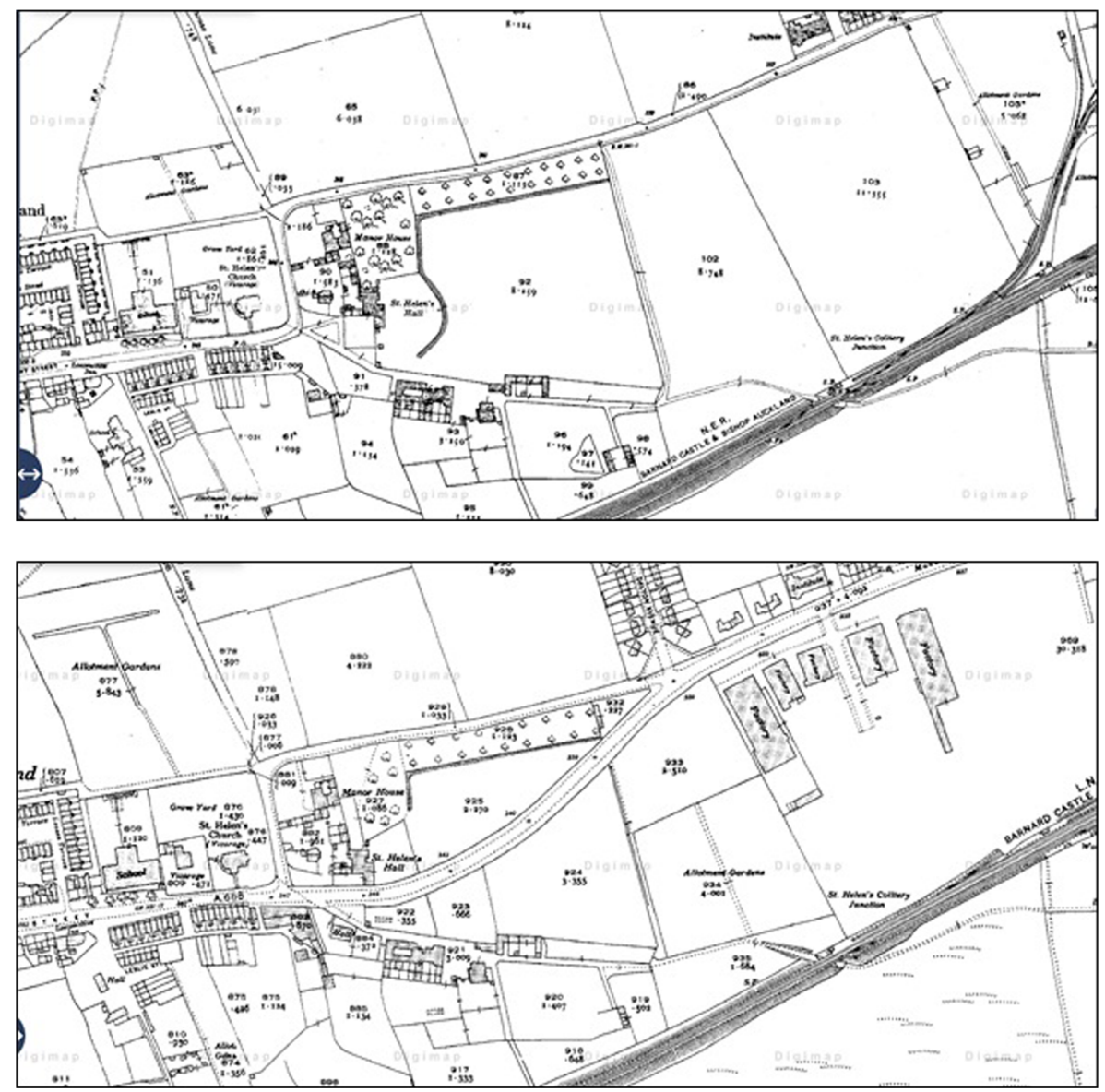

Fig. 4 Reworking of road layout at St Helen's Auckland following construction of new factories. (C) Crown Copyright and Landmark Information Group Limited. 2020. All rights reserved 
heading toward the railway station meant that the tight bends had to be smoothed out and a new road inserted round to the south side of the manor house (Fig. 4).

This attempt to realign the industrial base of this landscape was not the only change enacted under the Special Areas Act although it is important to remember this took place against the longer-term context of mines moving and closing as seams were worked out and new technologies emerged. A number of mines were entirely shut and demolished alongside their associated pit villages. The village at Eden Pit, described as "isolated and unattractive" (Bedfordshire Times, 1935) had earlier in the Depression been the focus of external charitable activity, with a school and a Rotary Club from Bedford (over $200 \mathrm{mi}[322 \mathrm{~km}$ ] to the south) sending clothing and bedding to support the community, as well as arranging for families to move to Bedford for employment and training. According to newspaper reports from 1935.

A social service centre has been formed, the committee elected, seeds and tools and manure for the small plots requisitioned and a bank manager in Shildon has taken on the treasurership [although] much remains to be done, allotments to be secured, a hut to be erected, streets to be levelled, a garden to be made, a playing place for the children to be provided, the houses to be painted outside and redecorated inside. Eden Pit can never become a Garden of Eden, but it need not remain a Slough of Despond. (Bedfordshire Times, March 8, 1935).

Despite this aspiration to invest in and rework the landscape, by 1938 the village and pit had been erased from the landscape utilizing statutory powers available under the Slum Clearance Act (1930) (Special Areas Commission 1938: 44). The spoil heaps associated with the colliery were seen as "unhappy reminders of the former activity prevalent in the Special Areas" (Special Areas Commission 1938: 48). At St. Helen's Auckland, the factories were built on platforms of hard-core derived from local pit heaps - others were levelled and used to fill in pit shafts and for preparing roads and construction sites, although some were landscaped and planted with trees (Special Areas Commission 1938: 45, 183).

More mundane interventions into the local landscape were carried out with financial support from the Special Areas Act. Public conveniences were constructed in Bishop Auckland, new sewerage was provided in a number of smaller settlements, streams were culverted, street lighting installed and a cricket field was provided with a new fence (Special Areas Commission 1936: 1938). This kind of ad hoc response to socio economic problems had already taken place before the introduction of the Special Areas Act. For example, in 1927, unemployed miners at Waterhouses were provided with work laying a new cricket pitch (Emery 1984: 155). Although relatively low-profile activities, these reflect a wider move toward improvement of daily life often with a focus on hygiene, exercise, and cosmetic improvements to the built environment. As a counterpoint to this, however, there were more ad hoc responses to the economic pressures placed on individuals. A good example of this is the establishment of a number of "caravan colonies" such as that at Thistleflats, Crook (Hartlepool Northern Daily Mail July, 1938; Temple 1940: 306-309) (Fig. 5). It is probably this site that was illustrated in the first edition of George Orwell's Road to Wigan Pier. Such colonies appear to have been a common feature of the Depression era landscape in towns in Northern England - and Orwell (1937: 61-62) described a similar colony in Wigan (Lancashire): 


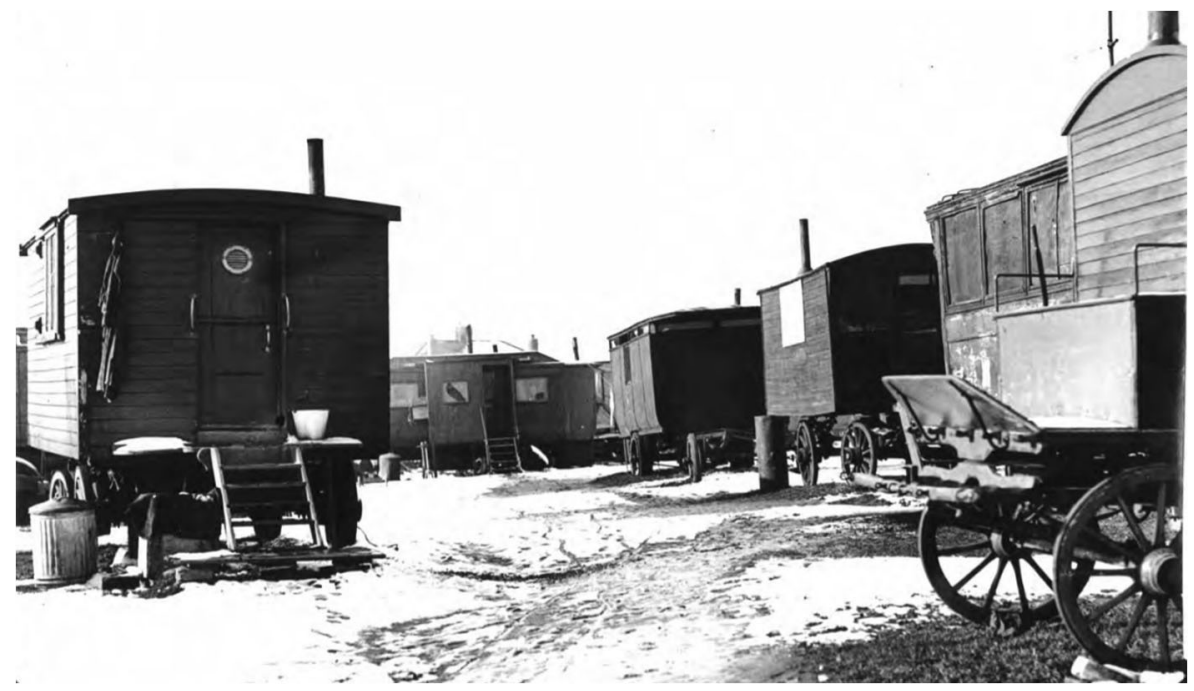

Fig. 5 Caravan Colony, Thistleflat, Crook (from Temple 1940) @ D Durham University

Some of them are actually gypsy caravans, but very old ones and in bad repair. The majority are old single-decker buses (the rather smaller buses of ten years ago) which have been taken off their wheels and propped up with struts of wood. ... One, for instance, measuring fourteen feet long, had seven people in it-seven people in about 450 cubic feet of space; which is to say that each person had for his entire dwelling a space a good deal smaller than one compartment of a public lavatory. The dirt and congestion of these places is such that you cannot well imagine it unless you have tested it with your own eyes and more particularly your nose... Water is got from a hydrant common to the whole colony, some of the caravan-dwellers having to walk 150 or 200 yards for every bucket of water. There are no sanitary arrangements at all. Most of the people construct a little hut to serve as a lavatory on the tiny patch of ground surrounding their caravan, and once a week dig a deep hole in which to bury the refuse. All the people I saw in these places, especially the children, were unspeakably dirty, and I do not doubt that they were lousy as well. They could not possibly be otherwise. The thought that haunted me as I went from caravan to caravan was, what can happen in those cramped interiors when anybody dies? But that, of course, is the kind of question you hardly care to ask.

While many of these initiatives were dotted across the landscape, meeting particular, specific, or contingent demands, there is one case of a larger transformation of a block of land directly connected to the Depression. Lying to the west of Bishop Auckland, the villages of Escomb, Etherley, and Witton Park, although lying on the western edge of the coal measures, had been the site of a series of coal pits as well as a substantial steel works at Witton. However, with rising costs of rail transport, the steel works shut in 1884. This in turn profoundly impacted on the local mines which lost their major market; the early twentieth century also saw a number of the major seams at local pits being worked out. As a result, this was a part of the landscape that had seen long-term decline in industrial employment, rather than being uniquely hit by the Depression. It 


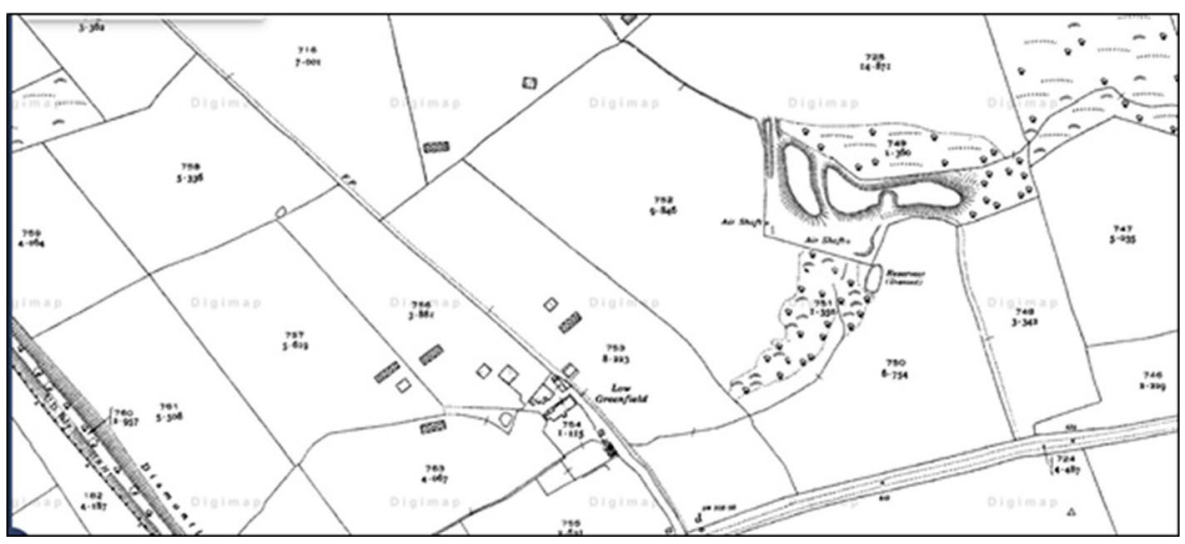

Fig. 6 Landscape of glasshouses and smallholdings in the Escomb-Whitton area (Co. Durham) (C) Crown Copyright and Landmark Information Group Limited 2020. All rights reserved

was into this area that a series of small-scale Land Settlement schemes were established by Durham County Council. Groups of between four and 40 smallholdings were laid out at Escomb, Toronto, and Etherley, including the construction of pig houses and "Dutch" glasshouses for tomatoes covering an area of over 160 ha (Fig. 6). Supplementing this scheme were a series of other developments including community buildings and huts, and at Toft Hill/Etherley, a former quarry was converted into a recreation field and sports ground, while a Social Service Centre was also constructed nearby (Special Areas Commission 1937: 104, 1938: 77-78). Rather unexpectedly, this area of land settlement and economic deprivation was also the site of a women's holiday camp centered at "The Field," Etherley.

\section{From Landscape to Site: Exploring Individual Interventions}

As well as this landscape scale analysis, more detailed study of four sites selected from across the wider northeast region was carried out - these were chosen to represent the diverse range of responses taken to address the economic crisis.

"Heartbreak Hill" was located in the ironstone mining area of East Cleveland and is the only one of the case studies which addressed problems outside the "Special Area." In response to the exceptionally high unemployment, local wealthy landowners, Ruth and James Pennyman of nearby Ormesby Hall, were instrumental in setting up a series of initiatives to alleviate the effects of worklessness (Chase 2000; Chase and Whyman 1991). A group of plots of land were rented - of which "Heartbreak Hill" was one. They were cleared by the unemployed miners and used to grow vegetables and keep pigs, goats, bees, and chickens. Costs were covered through selling some produce while the rest was shared among the members. A related cooperative sewing group for women was established, as was a workshop that developed into a furniture-making concern. The scheme brought together an unlikely alliance of the politically conservative James Pennyman, his more radically inclined wife Ruth, the miner's Union, leftist university students and a penumbra of politically engaged intellectuals including the 
composer Michael Tippett, painter and sculptor Wilf Franks, journalist David Ayerst, and Rolf Gardiner. The former three figures were key in a flurry of creative and artistic activity associated with the scheme, while the latter developed Nazi sympathies and after World War II became key in the post-war Organic movement (Chase and Whyman 1991; Moore-Colyer 2001). The Landscapes of the Great Depression conducted a program of fieldwalking at Heartbreak Hill. The locations of all artificial objects were recorded using RTK-GPS. All artifacts, aside from some in situ concrete and brickwork, were kept for analysis and conservation. Artifacts were recovered even if they were clearly post-1930s. Around half the site was walked; areas omitted were those not available due to waterlogging or the presence of livestock. The small amount of ceramics was analyzed by a specialist, while metal artifacts were identified via comparison with images in contemporary catalogues. Analysis of the glass was more problematic as typologies for the twentieth century UK do not exist, though it was possible to divide it into basic categories, such as vessel and window glass. Four standing buildings were also recorded both by the construction of 1:100 scale plans and thorough photographic survey; conforming as far as possible with Level 3 of the Historic England guidelines (Historic England 2016).

Hamsterley Forest Instructional Centre Lay in a rural area of Central Durham and was set up by the Ministry of Labour as a site where unemployed men were sent for 12week programs of physical reconditioning at the site of a Forestry Commission plantation (O'Donnell and Armstrong, forthcoming). Opened in 1934 it continued to be used until WWII when it became a Prisoner of War camp. While the men were called trainees, the camp did not actually attempt training other than what was necessary for them to carry out the work given. The camp itself comprised a system of wooden huts used for accommodation, as well as a canteen, recreation blocks, offices, and a sick bay. The men were also provided with sports facilities (swimming pool, football pitch). A wider infrastructure of roads and bridges within the forest was constructed by the trainees resulting in nearly $70 \mathrm{mi}(113 \mathrm{~km})$ of roads and tracks. They were also involved in a wider range of forestry management roles, including felling timber and nursery work. Fieldwalking was conducted here employing the same methods as at Heartbreak Hill. For health and safety reasons a number of artifact types were not recovered (specifically cigarette butts, sticking plasters, and food) none of these can have been connected with the 1930s site, however. Similarly, plastic cable ties and sweet wrappers were too numerous to recover but cannot be related to $1930 \mathrm{~s}$ activity. Aside from these items, all artificial artifacts were recovered whether or not they were related to 1930 s activity. All areas of the work camp site not currently under buildings or paving were walked, comprising the majority of the site (O'Donnell and Armstrong, forthcoming).

Swarland. As at "Heartbreak Hill" the establishment of the village at Swarland (Northumberland) by the Fountains Abbey Settler's Society (FASS) was a private philanthropic act. FASS was founded by Commander Clare Vyner, owner of a large private estate at Studley Royal/Fountains Abbey (North Yorkshire). The project saw the creation of a training camp for young men on his own Yorkshire estate at Fountains, and a more substantial project to create a village for workers and families (Northumberland Record Office [NRO] T/249 n.d.). The estate of Swarland Hall was bought in 
1934 and unemployed men from urban Tyneside were brought to the site with their families (Vaggs 2012). At first they were employed in construction work on the houses in the village, and later employment was created by the establishment of a brick works, a tweed mill and a joinery, while smallholdings surrounding the houses allowed the settlers to supplement their livelihoods with horticultural activity. No formal fieldwork was conducted at Swarland due to the difficulty of obtaining access to a sufficient proportion of the site, as it remains private houses and gardens. Visits to the village were made to ground-truth the manuscript research as far as possible.

Team Valley Trading Estate. While the other sites all, in some way, embraced agriculture, horticulture, or arboriculture, the final case study site, the Team Valley Trading Estate (Gateshead, Tyne and Wear) was unambiguously industrial in its motivation (Fig. 7). Supported by funding allocated via the Special Areas Act, the scheme offered a series of factories for rent, with the intention of stimulating new, mainly light, industrial activity through the provision of cheap, ready-made, properties. The project began in 1936, with the first factories being opened the following year. By the outbreak of war, around 100 factories were operating. They were used by a range of light industries, including food, clothing, and light engineering, as well as outposts of larger concerns, such as ICI and Cadburys. Considerable attention was paid to the wider landscaping and planning of the estate, which was overseen by the consulting architect, William Holford (O’Donnell and Armstrong 2020). Surveys were made of four factories conforming to

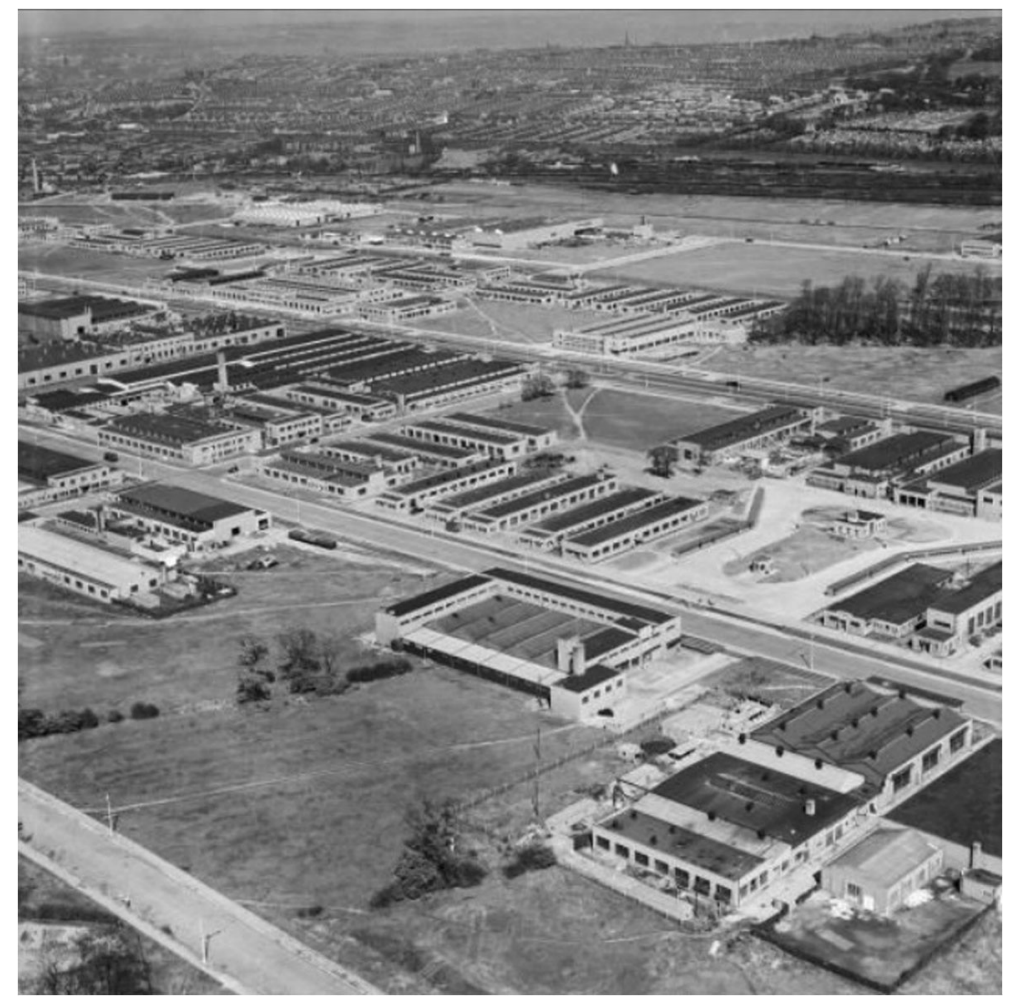

Fig. 7 Aerial view of the Team Valley Industrial Estate in the late 1930s @ C Historic Environment Scotland 
Level 3 of the Historic England guidelines (Historic England 2016). These represented the three "standard" factory types and one "bespoke" factory built to the specification of Sigmund Pumps, a Czech refugee firm. Measurements were taken to allow the construction of 1:200 scale plans and a thorough photographic record made.

Superficially, these four responses appear very different, encompassing a rural workcamp, a model village, cooperative labor schemes, and semi urban industrial activity. This immediately shows the diversity of responses to the Depression manifested as creative engagements with the environment. While they all responded to the economic crisis, the underlying principles that were articulated took two main approaches. The work camp at Hamsterley and the "Heartbreak Hill" scheme were initially primarily short-term mitigative strategies that aimed to provide occupation for unemployed workers until an economic upturn. These were conceived as interventions rather than critiques. Strategically, the enterprises took two differing approaches to providing support. At Hamsterley, the residents, primarily young unmarried men, were removed from their own localities and placed within a distinct and bounded space where they were kept busy and physically fit. The philosophy guiding this project portrayed the Depression as a temporary event during which workers required transitional support, but ultimately did not aim at a more fundamental reworking of the economic realities. Aspirations were simply for the participants to be kept fit for employment and be able to return to their jobs once the crisis had lifted (although only a fixed time was spent in the camp before the arrival of a new batch of trainees). The forestry training was primarily a bridging occupation before the resumption of usual service.

Equally, the "Heartbreak Hill" scheme provided intermediate activity and a supplementary food supply that might be maintained until the upswing of the next economic cycle allowed the men to return to their primary occupation as miners. Unlike at Hamsterley, there was not even any dislocation of residence; men engaged with the project while remaining in their own homes. However, here, some of those behind the project, especially Rolf Gardiner, did conceive of it as more than short-term relief, and framed it as a more permanent structural readjustment, moving the participants away from industrial employment toward agriculture as a primary source of income (O’Donnell and Petts 2019). A note of caution is required here, as the surviving discussions and reports on the site appear to have been written primarily by the more ideologically motivated external organizers and supporters of the project and may not reflect the views, expectations and assumptions of the local workforce themselves or even the Pennymans who initiated the scheme (Chase and Whyman 1991: 37; O’Donnell and Petts 2019; Teesside Record Office [TRO] U/PEN/11/32 n.d.).

The underlying sense that these projects were not permanent and the lack of relocation of family groups meant that the materiality of these two sites was relatively ephemeral in terms of impact on the landscape. Both sites clearly did rework some aspects of the environment -a key element of the "Heartbreak Hill" scheme was clearing of stones and undergrowth from the land. Yet, this was a relatively smallscale activity that reflected and engaged with existing practices already being carried out. At Heartbreak Hill, the creation of a new allotment and smallholding plot was not an innovation. Much of Britain had a long history of provision of allotments, small plots of land (usually less than a .25 ac [.10 ha]) made available by local government for non economic scale production of vegetables and fruit (Crouch and Ward 1997). 
They often allowed industrial workers the opportunity to supplement their main household income as well as providing important leisure and recreation. Emerging as a phenomenon in the second half of the nineteenth century, the weakly enforced Allotments and Cottage Gardens Compensation for Crops Act (1887) was buttressed by the Small holdings and Allotment Act (1908) which required local authorities to provide small allotment plots at low rents. Further land was requisitioned for allotments in WWI, although much returned to its owners following the end of the war. Demand continued though with the new Allotments Act (1925) consolidating municipal obligations to provide land. In this context, the "Heartbreak Hill" allotment scheme was not particularly innovative in terms of its material form. Even in the early twentieth century, there were at least six other allotments allocated to local industrial workers within $1 \mathrm{mi}(1.6 \mathrm{~km})$ of the site (Fig. 8). Its real distinctiveness was in the unusual coalition of labor unions and Conservative political interests who were involved in its establishment, rather than the local authority. Even here, this kind of local benevolence was not a novelty; in the 1880s, many allotments in the immediate area had been rented directly from the Skelton Estate (Daily Gazette for Middlesbrough 1887).

"Heartbreak Hill" was not a fundamental break from the past, merely the latest iteration of an established mode of dealing with economic precariousness in an area vulnerable to industrial and economic downswings. The project differs from neighboring allotments by its cooperative nature, evidence for which has been revealed by our fieldwork. Space within the Heartbreak Hill site, where we performed fieldwork, was organised for collaborative work rather than into individual plots with similar facilities (Petts et al. 2018). Nearly all buildings were placed on the slope on the east of the site

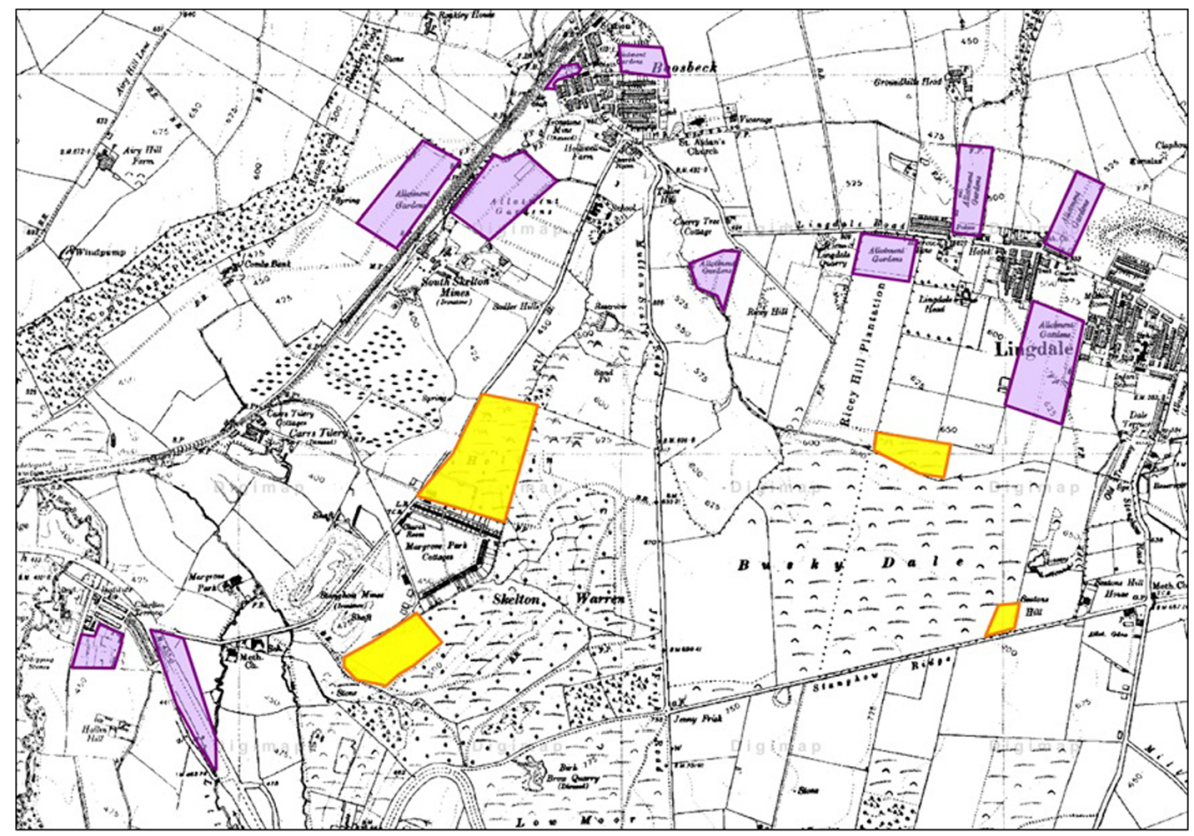

Fig 8 Distribution of earlier allotments (purple) in relation to "Heartbreak Hill" (yellow) (C) Crown Copyright and Landmark Information Group Limited. 2020. All rights reserved 
so as to leave the flattest ground free for cultivation. These buildings were organized in clusters according to function (Fig. 9). A group in the south of the site contained four structures. Three still stand while one survives only as a surface scatter of building material and some in situ concrete floor. The longest of these structures shows evidence for having been extended to double its length by the creation of a second bay. The unusual brick and stone construction of the southern wall allows this to be identified as a pig sty by comparison with contemporary photographs (Chase and Whyman 1991: 48). Ordnance Survey plans and surviving traces of boundary walls shows that each bay of the pig sty had a separate enclosure in front of it. Both of these enclosures contained a further hut. That to the east has the remains of a hearth suggesting that people spent some time in these huts perhaps during farrowing. While this arrangement

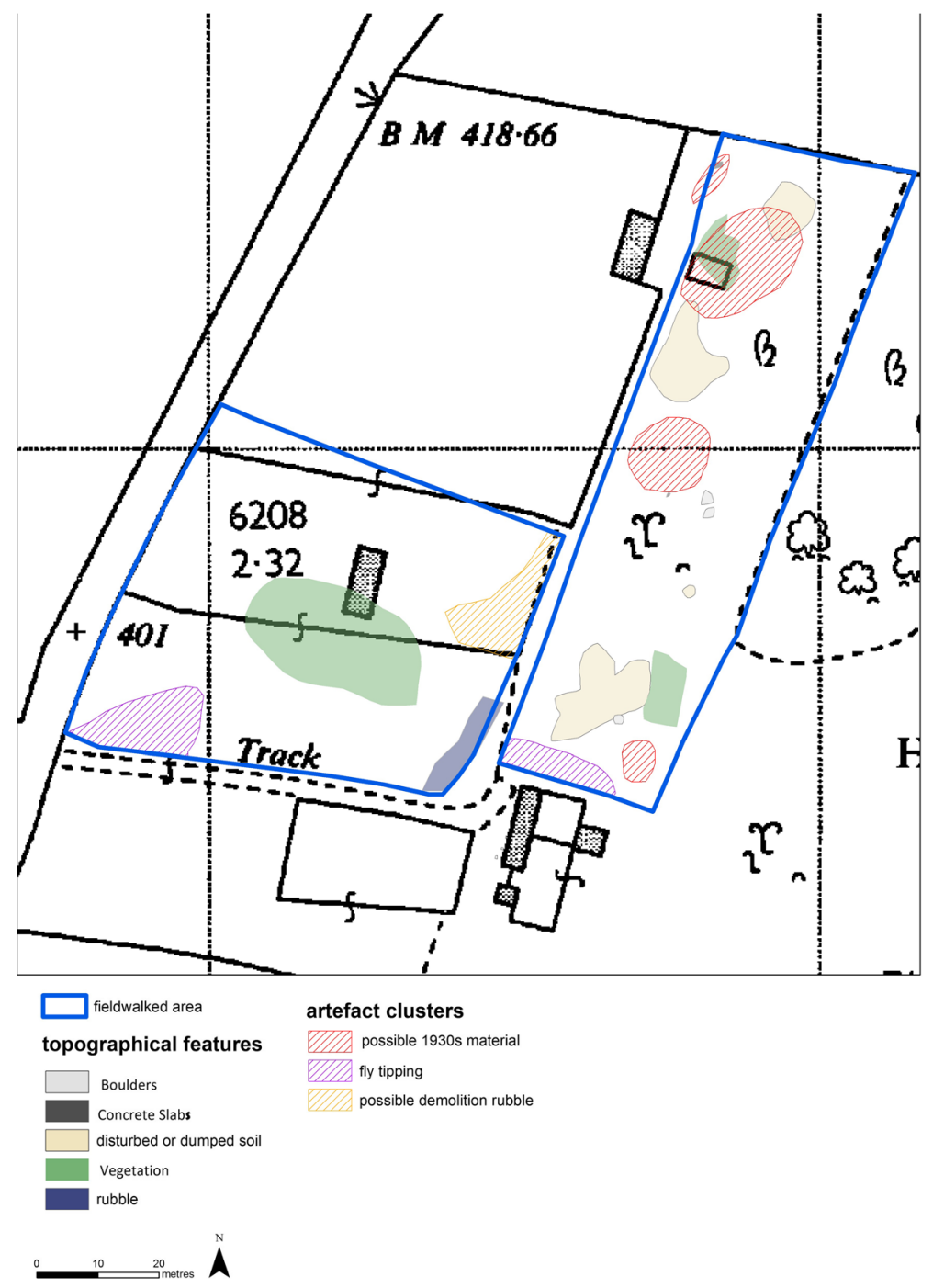

Fig. 9 Plan of "Heartbreak Hill" () Durham University 
implies individuality in pig keeping sufficient to require two sets of facilities, these were provided in a specific pig-rearing area of the site rather than on individual allotment plots. A light scatter of possible 1930s bottle glass and ceramics were found next to this building cluster. A second cluster of buildings in the north contained a much larger hut which is probably too large to have belonged to an individual. It also differed from those in the southern group by having a slate roof while the piggery buildings had corrugated iron or concrete asbestos. This may have been the centre of activity in this branch and so was distinguished visually. A second possible 1930s structure was revealed by in situ concrete floor and building material surface scatter. The third building in this area is a semi-circular concrete asbestos hut of a type not manufactured until the Second World War and so post-dates the 1930s allotments. A scatter of possible 1930s bottle glass was also found around these buildings. A further surface scatter of window glass and brick as well as some in situ brickwork revealed a further structure between the two clusters. No bottle glass or ceramic was recovered from this area and so it is likely that this is the remains of a cold frame. Animal bone from this area may imply the use of domestic refuse for fertiliser (Rowly-Conwy, pers. comm.). The flatter land to the west contained only one building. Fieldwalking recovered no evidence for it because its site is now occupied by a dense patch of stinging nettles (Urtica dioica). This probably means that this was used for livestock and was perhaps placed near the fields for the convenience of spreading the manure. Ordnance Survey plans and contemporary photographs suggest that these areas were divided into three large fields, not individual plots (TRO U/PEN/11/2). Overall, the arrangement of the site implies that the cooperative ethos was fundamental in structuring the use of space at Heartbreak Hill which made it clearly different from other allotments nearby. Cooperative allotments are not unknown in the Northeast, one had for instance operated at Clousden Hill on Tyneside at the turn of the nineteenth and twentieth centuries (Todd 1986). James Pennyman was well aware of the radical left-wing history of cooperative horticulture through correspondence with JW Scott (TRO U/PEN/11/26); equally, involvement with Trade Unionism probably had made many of the miners aware of such schemes. It does appear, however, to have been a departure for East Cleveland specifically. Consequently, the scheme built upon the practical experience of the miners in allotment gardening and their and James Pennyman's theoretical understanding of cooperation to create something new for the area, while still reflecting Pennyman's wider social context as a traditional Conservative landowner.

The work at Hamsterley was in some ways more substantial, leading to a greater reworking of the landscape; workcamp-labor constructed bridges and roads in the pre existing forestry plantation and carried out some planting and other arboricultural tasks. Yet, it was an engagement with an existing forestry scheme rather than creating a new landscape from a blank canvas. The provision for accommodation and amenities for the participants, placed in wooden huts, with some limited associated landscaping, was typical of material provision of accommodation for large-groups of single men (Fig. 10). It drew on a pre existing repertoire of temporary sites, most explicitly, the army camps and prisoner-of-war camps that were constructed on a large-scale during the Great War, which had a distinctive vocabulary of barracks, mess halls and latrines (cf., Carpenter et al. 2018; Draper 2017). Much of the material infrastructure was constructed partly by trainees from another regional Training Centre (Wallsend), with the rest supplied commercially. Never intended to be permanent and fitted to deal with waves of transient 


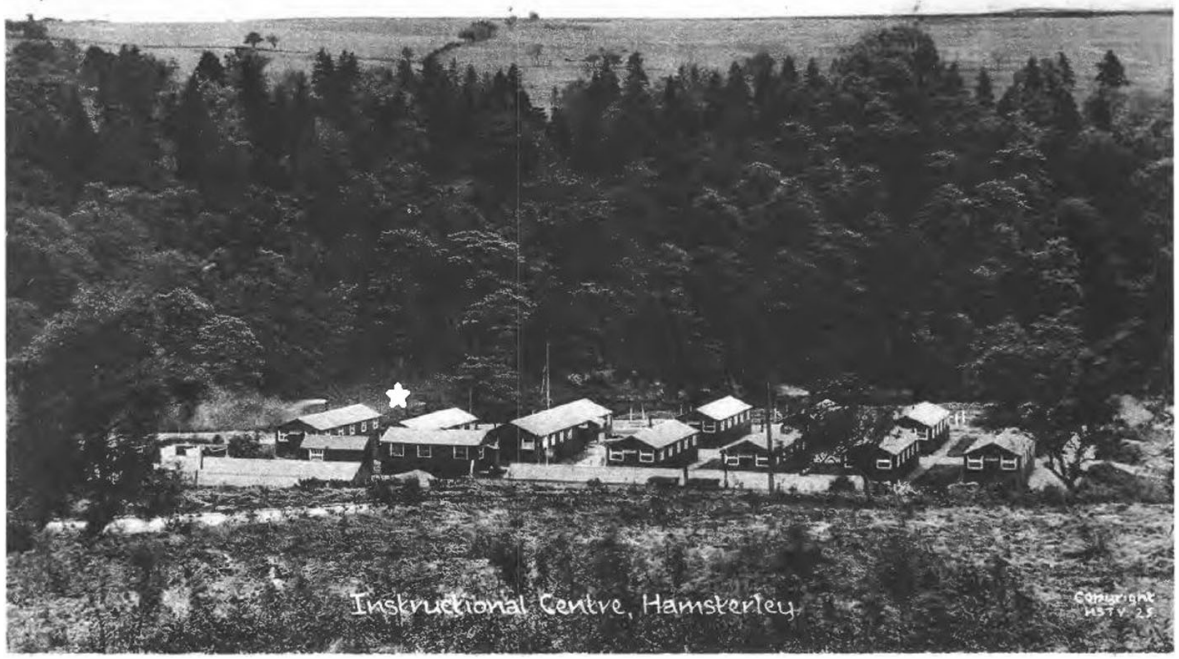

Fig. 10 Contemporary photograph of the Hamsterley Forest Instructional camp ㄷ Forestry Commission

groups of residents, in occupation for short periods of time before moving on, military camps provided a ready-made template for workcamps; indeed a new arrival to Hamsterley in 1934 recalled "The Camp was typically army style, all the huts were new and shining corrugated iron cladding" (Rendle 2003). There was no attempt to identify particularly novel or experimental approaches to managing and deploying space and labor. The multivalency of the camp infrastructure at Hamsterley can be seen in its subsequent repurposing as a Prisoner Of War camp during World War II.

Despite their clear attempt to meet a crisis in industry through redirecting workforces to engagement towards more clearly rural tasks, they do not fit into the more developed model of "land settlement" projects that flowered in this period. Initiatives such as the Land Settlement Association (LSA) not only aimed to provide training and rework employment structures, but also to physically and permanently relocate not just the workers but their entire families (Clarke 1985; Daniels 2010; Dearlove 2000; Linehan and Gruffudd 2004; Wade-Martins 2006). These were as much social as economic projects. In some cases, workers and their families could be moved considerable distances; the LSA for example moved groups from County Durham to sites in the south of the country. The Land Settlement Association settlements were very much focused on intensive horticulture - vegetables and fruit - as well as chickens and pigs for nearby urban markets rather than more extensive farming of wheat and other cereals or sheep and cattle pasturing. The smallholdings were around 5 ac (2.0 ha) in size; too small for serious extensive farming. Ironically, the back-to-the-land movement was economically predicated on nearby urban markets for their goods and reflected a perior sub urban landscape rather than a truly rural one - the importance of the produce actually reaching their consumers was reflected by the provision of centralised packing, marketing, and distribution (Clarke 1985: 85, 151).

The LSA approach was also very different to that which took place at Swarland. Here, although smallholdings were provided for the incoming families from Tyneside, they were even smaller than typical LSA plots - only around 1.5 ac (.61 ha) in size. Although the project involved a physical displacement to the countryside, it was not 
fundamentally anti-industrial. Once the men had constructed the houses, it was intended that they would go on to work in small-scale industrial concerns, including a brickworks at Thrunton and a sawmill and joinery at Amble, both about $10 \mathrm{mi}$ (16 $\mathrm{km}$ ) away, as well as a small tweed mill in the village itself (Vaggs 2012). Unlike the traditional industrial villages of the northeast, where the labor force was housed in the immediate vicinity of their place of employment, Swarland had a different pattern. The lack of immediate proximity of employment for the new settlers required the workforce to travel, paradoxically maintaining the rural aspect of a settlement still underpinned economically primarily by industrial labor.

The smallholdings were clearly only intended to supplement the wages or diets of the workers, with no formal plan for centralized distribution or marketing. This kind of semi-structured provision of smallholdings to provide a complimentary income to that provided by a male wage earner was not a new departure in Northeast England; further west in the North Pennines, a miner-smallholder/farmer landscape had been established as early as the early nineteenth century (Hunt 1970: 156-157). However, the small scale of both the Swarland and North Pennines holdings means that they can only ever have been able to provide a limited supplement to household consumption. In the case of Swarland, it seems that the ultimate plan may have been for some individuals to take over the small holdings of others and build up to more economically sized farms, although due to the structure of the settlement at Swarland with each plot laid out around the house of its owner, it is not easy to see how this might have been achieved in practice.

Unlike LSA properties and schemes such as "Heartbreak Hill" Swarland did have distinctive features. First, while it did not provide communal agricultural facilities, it did aspire to the establishment of a rural "community" through provision of communal social facilities, including a village hall and a range of playing fields and sports facilities. A number of small shops surrounding a notional "village green" also served to provide a focal point for the new village. The provision of a school in 1937 was also important to consolidating social cohesion within the new community (NRO CES/204/1/1). Here, there was clearly an attempt to hark back to the notion of the 'organic' rural village, dominated by small-scale face-to-face relationships rather than being underpinned vertical hierarchies (O'Donnell and Petts 2019). However, two aspects of the traditional village that were not to be found at Swarland were the manor house and the church; Swarland Hall itself, a substantial eighteenth-century stately home was demolished as part of the process of converting the adjacent parkland into the new model village. Although the village hall was also used for church services, it remained a multifunctional structure. The founder, Vyner, later stated that there had been plans to build a church, but they were never completed due to the outbreak of war (NRO T/249). Clearly, though, the provision of a permanent religious focus was very much a secondary aspiration.

Despite the nostalgic flavor to much of Swarland's ethos, it seems not to have extended to reproduction of physical foci of social hierarchy, either religious or secular. This was however not the original intention and emerged from a process of plan development in early 1935. The first plan submitted to the Alnwick Rural District Council (RDC) for planning permission was submitted in January 1935 (NRO NRO/ $756 / \mathrm{D} / 2 / 43$ ). In this plan the public buildings including shops, workshops, and packing sheds were to be in the center of the village (close to the present square). The vicarage, 
church, church hall, and schoolmaster's house formed a group near to the public buildings. Consequently, in this earliest plan, the church and houses of two prominent members of the village dominate its center while an important community space, the hall, is controlled by the church. These buildings were to be visually prominent at the end of the main road leading past the other public buildings. By June 1935 these plans had changed significantly as the block plan for the general store depicts part of the central area. This shows the village hall alone at the end of the main road in the space once occupied by the church. The schoolhouse has been moved further west down the road toward the school (NRO NRO/456/D/2/44). In January 1936, a layout plan of the entire village was drawn (NRO NRO/756/D/2/77). In this plan most of the public buildings, some of which were under construction, were shown as they were built. No vicarage or schoolmaster's house are shown and the school is also not depicted, it is possible that by this time it was known that the school would not be built on Settlers' Society land. The village hall is shown in the position it occupied on the June 1935 block plan, while a chapel was to be placed further west near to the slaughter house. In actuality no chapel was ever built, though Vyner stated in the 1980s that this was only because the start of the war had truncated their plans (NRO NRO/3783). The village hall was also moved to a site behind the shops which was much less central but provided space for a great variety of facilities. The houses of some of the community's prominent members did however make their way back into the center of the village. The nurse's house was built close to the position of the school master's house on the January 1936 plan, while a pair of semi-detached houses between the shops and the school were probably for society staff as they have garages and front parlors which are absent from other Swarland houses (NRO NRO/756/D/2/256, NRO NRO/756/D/2/ 264). However, while these high-status individuals lived near the center of the village, none of these houses are on main roads and they are not obviously visually distinct from any other Swarland houses. Vyner implied in interviews that he had not wanted to create a settlement which he personally dominated at "squire" (NRO NRO/3783), and perhaps therefore did not want the Settlers' Society or church to dominate it either. This may be the reason for the rapid change of symbolic focus from church and schoolmaster to the village hall representing the whole village and over which the settlers exercised a great deal of control. The better facilities provided in the staff houses imply that hierarchy still existed but their modest position suggests that social status was not to dominate, at least obviously, all aspects of village life.

\section{Bodywork}

One theme that threads through these diverse responses to the economic crisis was the underpinning belief that reform of the workforce was not simply a process of providing training and skills enhancement but also required "bodywork" improving the physical health of the unemployed. The impact of unemployment and urban poverty on the physique and health of the British worker had been a major issue of social concern in many circles since the late Victorian period (Zweiniger-Bargielowska 2010). The Depression itself seems to have particularly exacerbated inequalities in public health in our study region (Langthorne and Bambra 2019). A key underpinning assumption at play was that industrial production and the associated periods of unemployment 
inherent in the rise of a complex industrial society took its toll on the physical health and well-being of the working classes. "Healthy" outdoors labor was replaced by indoor occupations in unhealthy polluted atmospheres, alongside an inadequate and limited diet, that served to impair and stunt physical development of the workforce. This had military implications, as modern warfare moved toward models of mass conscription, resulting in an increasingly unhealthy reservoir of fighting men.

The importance of the provision of sporting facilities is apparent at many of our case study sites. The Hamsterley Forest workcamp included among its facilities a swimming pool and a football pitch (Field 2012: 159). Swarland also had sporting provision physically and metaphorically placed at its heart - Team Valley also saw the facilities for physical recreation planned alongside the construction of workspaces, though the advent of war prevented this being built. More widely, physical training classes for unemployed men in the Special Areas were organized by the Ministry of Labour (Special Aarea Commission 1938: 63). The emphasis on the reviving quality of outside physical labor whether through agriculture, horticulture, or forestry, had a wider spatial impact, with some schemes, such as Swarland, Hamsterley, and the wider range of Land Settlement Authority initiatives, requiring the physical displacement, either temporarily or permanently, of the participants from their original homes.

A unifying feature of many of the initiatives providing support for unemployed men was a concern with weighing them (cf., Field 2013: 166), and an improved diet was also an important aim for many of the projects. At Heartbreak Hill, most of the output was intended to enhance the diet of the workers and their families. The smallholdings at Swarland would also have provided a wider range of fruits and vegetables for the inhabitants than would have been available in the heavily developed industrial housing areas of urban Tyneside. Team Valley had canteens which provided a menu which was purportedly scientifically designed to provide the necessary nutrition for the working day at a reasonable price (Sunderland Daily Echo July 13, 1938, NRO 1395/3437). The extent to which diet in instructional centers such as Hamsterley was good is more debateable, despite the rhetoric of good quality catering at such sites, it saw 150 men go on strike due to complaints about the food in 1939 (House of Commons Debates 1939).

The focus on physical health was also a gendered one. Physical labor was seen primarily as the realm of the male body. While women were clearly expected to work, for example, in the light industrial manufactories in Team Valley or the tweed mill at Swarland, this was primarily inside and at tasks which prized manual dexterity rather than physical strength and stamina (Field 2013: 173-191 ). As a result, the female body was treated differently; women were not generally expected to engage in the agricultural labor that was key to some of the "ruralist" responses to the economic crisis, although the placing of smallholdings around the houses at Swarland may have implied that some level of domestic engagement in horticulture if not agriculture was expected. The expectation that even working women would be primary in childcare may also explain why at Swarland, while men moved outside the village to industrial workplaces, the women's main employer, the tweed mill, lay at the very center of the village. Architectural plans for the tweed mill show that a "Creche or Playroom" was initially planned to form part of the mill complex though it was never actually built (NRO LAR/ $\mathrm{G} / 2 / 2 / 2 / 88)$. 


\section{Conclusions}

The scale of the Depression and its central role in historiography as the first major crisis of modernity means that the responses to it are often seen as innovative or novel. However, in both general and specific ways these responses are often rooted in a history of material engagement with crisis. The Northeast had been through a series of economic crises since the later nineteenth century; this had resulted in a pattern shortterm and long-term responses to economic instability going back at least 50 years. Although the international articulation of the Depression was distinctive, depression and economic crisis was not a new phenomenon; the region had been through the "Long Depression" of the late 1800s (1873-90s) and a depression in the early 1920s following the initial post-WWI economic boom, which lead up to the General Strike of 1926 (Crafts 2014; Musson 1959) While, the scale may have been global, in Northeast England its articulation was profoundly rooted in locality, a locality that had seen periodic economic crisis before. Its response to economic problems was thus not entirely novel, but often rooted in re-arrangements and adoptions of earlier strategies (cf., Brittain 2017; Hadfield 1970; Tarlow 2002). It played out within the constraints and affordances of a pre-existing landscape addressing and engaging with the residues and responses to previous cycles of crisis in capital production and accumulation as well as the most recent one. Some elements of these earlier landscapes, such as allotments were the materialized versions of social response to the flaws of the system, others, such as colliery spoilheaps were the material residues of capitalism itself (cf., Davies and Lawrence 2019; Linehan 2000). These new responses involved processes of both accretion (new workcamps, new roads, new allotments) as well as processes of erasure (removal of villages and spoil heaps) that served to delete elements of a sedimented landscape of capital.

Moving beyond the immediate discussion about antecedents of the various projects, there is a wider, primarily rhetorical debate, about the extent to which they oriented themselves to the past and the future; were these romantic engagements with a notion of wider rural past or were they more self-consciously modernist in outlook? Some responses, such as Swarland and Heartbreak Hill took a broadly "ruralist" approach, seeing the industrial crisis as reflecting an inherent flaw in industrial capitalism which could only be saved by a return to the land, whereas initiatives such as at Team Valley although engaging critically with the existing structure of the economy of the region, saw it as something that could "retooled" with a shift from heavy to light industry, which itself resulted in shifts in the spatial location of industry and the nature of the workforce (O'Donnell and Petts 2019). Significantly, these two approaches cross-cut simplistic political distinctions; indeed more widely, while to modern eyes the 1930s might be seen through the lens of a metanarrative of rising tensions between "left" and "right," ultimately resulting in WWII and the "Cold War," this ignores the complexity on the ground that saw proto-Fascists such as Rolf Gardiner cooperating with local mine unions and leftist campaigners such as Ruth Pennyman. It was a time of political experimentation and unorthodoxy, including the flowering of such ideologies as guild socialism and the social credit movement.

An appreciation of how these competing and overlapping intentions played out "on the ground" help to unpick the motivations that resulted in the changes to landscape we plotted. For example, the reaction to this crisis in modernity involved both backward- 
looking "ruralist" approaches and more "scientific" perspectives aiming to restructure capitalism, yet both had complex relationships to industry and technology, with many back to the land initiatives embracing agricultural technology and innovation (such as new forms of greenhouse and centralized packing facilities) and ultimately being predicated on the presence of industrial population nearby to provide a market for their goods. Equally both approaches often placed "bodywork" at the heart of their activities, with workers and activists of all political persuasions seeing body and gender relations as subjects for engagement and intervention, even if the underlying motivations may have been different.

Ultimately, the responses to the Depression in northeast England, whether driven by government, charities, activists or simply small-scale individual responses were diverse and enacted through a process of bricolage, selecting a range of responses, actions and strategies, some tried and tested with their origins in earlier responses to industrial and social crisis that had been taking place in the region over the longue durée, while others were new, innovative, and driven by new managerial, technocratic and scientific critiques and approaches to tackling a crisis in capitalism. Equally, even in this part of Britain, at the epicenter of some of the most profound impacts of the crisis, for many, it was a time of rising consumerism and improving aspirational lifestyles; indeed, paradoxically, it was the presence of a market for consumer goods that underpinned the very light engineering factories constructed as a response to the Depression at Team Valley, Bishop Auckland, and elsewhere.

Returning to Harvey's (2001) three modes of representing space (built environment, representation of space, spaces of representation) these provide a useful way of considering the impact of the Depression on the landscape. There are practical physical impacts on the built environment of the region - the materiality of re-aligned roads, removed spoilheaps, and industrial estates. These are the most obvious and direct ways in which economic crisis is made manifest in the spatial fabric of the region. However, many of these material changes were underpinned by, framed, and fed into wider representations of space. For example, decisions about the architectural idiom of the buildings at Swarland and its wider spatial planning entered into a dialogue with contemporary debates about the relative merits of industrial modernism and "back-tothe-land" ruralism - debates which were as much about the way in which aesthetic representations of space intersected with social, political, and economic critiques (cf., Marsh 2010; Matliss 1998; Meredith 2006; O’Donnell and Petts 2019) - such debates ranged across the all three of Harvey's spatial domains embracing actual space, images of space and dreams of space. Equally, the refined modernist design of the buildings at Team Valley, were not just designed as containers of restructured industry, but as part of a landscape which told stories about a new way in which an industrial Northeast might be made manifest. It was represented in brochures and posters, an acted as a model for what a newly reconstituted post-Depression region might look like. Within its built environment resided an immanent space of representation in a dialogue with an imagined future. It is perhaps by using these different ways of thinking about space that the true importance of understanding the physical impact of the Depression can be seen. Analyzing the built environment and its relationship to wider debates about space show how reactive and proactive responses to the Depression drew on existing discourses, model, and memories of how space had confronted crises in the past. Equally it shows how space and materiality were themselves an important constitutive element in 
debates about how the future might be fashioned. Ultimately, the materialized landscapes of Depression were as much spaces of experimentation and yearning as reactions to crises and discontent.

Acknowledgments The Landscapes of the Great Depression team would like to thank all those who have contributed to this project, particularly the project advisory group, Jonathan Finch, Dan Hicks, Quentin Lewis, Andrzej Olechnowicz and Martyn Watts. Thanks also to Jon Libbon, Haeden Stewart and Kimberley Wooten who all provided material to help us better understand the wider context of our work. This work was funded as the Landscape Archaeology of the Great Depression project by the Leverhulme Trust (Research Project Grant RPG-2016-076).

Open Access This article is licensed under a Creative Commons Attribution 4.0 International License, which permits use, sharing, adaptation, distribution and reproduction in any medium or format, as long as you give appropriate credit to the original author(s) and the source, provide a link to the Creative Commons licence, and indicate if changes were made. The images or other third party material in this article are included in the article's Creative Commons licence, unless indicated otherwise in a credit line to the material. If material is not included in the article's Creative Commons licence and your intended use is not permitted by statutory regulation or exceeds the permitted use, you will need to obtain permission directly from the copyright holder. To view a copy of this licence, visit http://creativecommons.org/licenses/by/4.0/.

\section{References}

Anonymous. (2013). A Historical Context and Archaeological Research Design for Work Camp Properties in California California Department of Transportation, Sacramento.

Barker, B. and Lamb, L. (2009). The archaeology of poverty and human dignity: charity and the work ethic in a 1930s Depression era itinerant's camp on the Toowoomba Range Escarpment, Queensland Archaeologies 5: 263-279.

Bradley, A., Buchli, V., Fairclough, G., Hicks, D., Miller, J., and Schofield, J. (2004). Change and Creation: Historic Landscape Character 1950-2000 English Heritage, Swindon.

Bedfordshire Times. (1935). A Black spot in Durham: Derelict Village of Eden Pit. March 8, p. 12.

Brittain, M. (2017). Ouse Washland Archaeology: Manea Colony Investigations Cambridge Archaeology Unit, Cambridge.

Buchli,V. and Lucas, G. (2001). Archaeologies of the Contemporary Past, Routledge, London.

Bulmer, M. (1978). Mining and Social Change: Durham County in the Twentieth Century. Taylor and Francis, London.

Carpenter, E., Knight, D., Pullen, R., and Small, F. (2018). Cannock Chase, Staffordshire: The Chase Through Time, Historic England Contribution Historic England, Swindon.

Chase, M. (2000). Heartbreak Hill: environment, unemployment and "Back to the Land" in inter-war Cleveland. Oral History 28(1): 33-42.

Chase, M. (2010). Unemployment without protest: the ironstone mining communities of East Cleveland in the inter-war period. In Reiss, M. and Perry, M. (eds.), Unemployment and Protest: New Perspectives on Two Centuries of Contention. Oxford University Press, Oxford, pp. 265-282.

Chase, M. and Whyman, M. (1991). Heartbreak Hill: A Response to Unemployment in East Cleveland in the 1930s. Cleveland County Council, Cleveland.

Clarke, P. (1985). The Land Settlement Association 1934-1948: TheEvolution of a Social Experiment. Doctoral dissertation, London School of Economics and Political Science, London.

Crafts, N. (2014). Walking Wounded: The British Economy in the Aftermath of World War I. https://voxeu.org/ article/walking-wounded-british-economy-aftermath-world-war-i

Crouch, D. and Ward, C. (1997). The Allotment: Its Landscape and Culture. Five Leaves, Nottingham.

Daily Gazette for Middlesbrough. (1887). Allotments in Skelton. November 5, p. 3. https://www. teesarchaeology.com/projects/Heritage_of_Hart/documents/HeritageofHart2010_Smallholdings.pdf 
Daniels, R. (2010). Heritage of Hart Project 2010: An Historic Environment Survey of the Smallholdings at Hart, Hartlepool. Tees Archaeology (TA: 10/16) https:/www.teesarchaeology.com/projects/Heritage_ of_Hart/documents/HeritageofHart2010_Smallholdings.pdf

Davies, P. and Lawrence, S. (2019). Engineered landscapes of the southern Murray-Darling Basin: Anthropocene archaeology in Australia. Anthropocene Review 6(3): 179- 206.

Dawdy, S. (2006). The taphonomy of disaster and the Reformation of New Orleans. American Anthropologist 109(4): 719-730.

Dearlove, P. (2000). Fen Drayton, Cambridgeshire: an estate of the Land Settlement Association. In Thirsk, J. (ed.), The English Rural Landscape. Oxford University Press, Oxford, pp. 324-335.

Draper, K. (2017). The Development, Typology and Identification of Temporary Military Buildings in Britain 1914-1945. DPhil thesis, University of Cambridge, Cambridge.

Emery, N. (1984). Pease and Partners and the Deerness Valley: Aspects of the Social and Economic History of Waterhouses, Esh Winning and Ushaw Moor. Master's thesis, Durham University, Durham.

Field, J. (2012). An anti-urban education? work camps and ideals of the land in interwar Britain. Rural History 23: 220-224.

Field, J. (2013). Working Men's Bodies: Work Camps in Britain, 1880-1940. Manchester University Press, Manchester.

Garside, W. R. (1990). British Employment, 1919-1939: A Study in Public Policy. Cambridge University Press, Cambridge.

González-Ruibal, A. (2019). An Archaeology of the Contemporary Era. Routledge, London.

Gray, N. (2017). The Worst of Times: An Oral History of the Great Depression in Britain. Routledge, London. Hadfield, A. M. (1970). The Chartist Land Company. David and Charles, Newton Abbott.

Harrison, R. (2009). Towards and archaeology of the welfare state in Britain, 1945-2009. Archaeologies 5(2): 238-262.

Harrison, R. and Schofield, J. (2010). After Modernity: Archaeological Approaches to the Contemporary Past. Oxford University Press, Oxford.

Hartlepool Northern Daily Mail. (1938). Under the hammer. July 11, p. 5.

Harvey, D. (1990). The Condition of Post-Modernity. Oxford University Press, Oxford.

Harvey, D. (2001). Spaces of Capital: Towards a Critical Geography. Edinburgh University Press, Edinburgh.

Hewitt, R. (2011). An Archaeological Assessment of County Durham: The Aggregate Producing Areas. Durham County Council, Durham.

Historic England. (2016). Understanding Historic Buildings: A Guide to Good Recording Practice. Historic England, Swindon.

Hobsbawm, E. (1994). The Age of Extremes: A History of the World, 1914-1991. Vintage, New York.

House of Commons Debates. (1939). March 23, column 1427-8; http://api.parliament.uk/historic-hansard/ commons/1939/mar/23/instructional-centres

Howkins, A. (1991). Reshaping Rural England: A Social History, 1850-1925. Harper Collins, London.

Hunt, C. J. ( 1970). The Lead Miners of the Northern Pennines in the Eighteenth and Nineteenth Centuries. Manchester University Press, Manchester.

Johnson, M. (1996). An Archaeology of Capitalism. Blackwell, Oxford.

Langthorne, M. and Bambra, C. (2019). Health inequalities in the Great Depression: a case study of Stockton on Tees, North-East England in the 1930s. Journal of Public Health 42(2): 1-8.

Leone, M. (1995). A historical archaeology of capitalism. American Anthropologist 97(2): 251-268.

Lewis, Q. (2016). An Archaeology of Improvement in Rural Massachusetts: Landscapes of Profit and Betterment at the Dawn of the $19^{\text {th }}$ Century. Springer, New York.

Libbon, J. (2012). We had everything but money: a study of buying strategies at a civilian conservation corps camp in the Allegheny National Forest. Pennsylvania Archaeologist 82(2): 54-63.

Linehan, D. (2000). An archaeology of dereliction. Journal of Historical Geography 26: 99-113.

Linehan, D. and Gruffudd, P. (2004). Unruly topographies: unemployment, citizenship and land settlement in inter-war Wales. Transactions of the Institute of British Geographers. 29(1): 46-63.

Loebl, H. (1978). Government-Financed Factories and the Establishment of Industries by Refugees in the Special Area of the North of England, 1937 - 1961. Doctoral dissertation, Durham University, Durham.

Loebl, H. (1988). Government Factories and the Origins of British Regional Policy, 1934-1948: Including a Case Study of North Eastern Trading Estates Ltd. Aldershot, Avebury.

Malpass, P. and Jones, C. (1996). The "fourth experiment"? the Ministry of Health, the Commissioner for Special Areas and the North Eastern Housing Association. Planning Perspectives 11(3): 303-321.

Marsh, J. (2010). Back to the Land: The Pastoral Impulse in Victorian England, 1880-1914. Faber and Faber, London. 
Matliss, D. (1998). Landscape and Englishness. Reaktion, London.

Matthews, C. (2012). The Archaeology of American Capitalism. University Press of Florida, Gainesville.

Meredith, A. (2006). From ideals to reality: the women's smallholding colony at Lingfield, 192039. Agricultural History Review 54: 105-108.

Moore-Colyer, R. J. (2001). Back to basics: Rolf Gardiner, H. J. Massingham and "a kinship in husbandry." Rural History 12(1): 85-108.

Musson, A. E. (1959). The Great Depression in Britain, 1873-1896: a reappraisal. Journal of Economic History 19(2): 199-228.

Northumberland Record Office (NRO). (n.d.). Queen Elizabeth II Country Park, Ashington.

O’Donnell, R. and Petts, D. (2019). "Rural” rhetoric in 1930s unemployment relief schemes. Rural History 30(1): 53-69.

O'Donnell, R. and Armstrong, K. (forthcoming). A global phenomenon in County Durham: Fieldwork at the Hamsterley Forest Instructional Centre Work Camp. Durham Archaeological Journal.

O'Donnell, R. and Armstrong, K. (2020). The archaeology of 20th century factory management: four factories on the Team Valley Trading Estate. Industrial Archaeology Review. https://doi.org/10.1080/03090728. 2020.1799523

Olechnowicz, A. (1997). Working Class Housing in England between the Wars. Oxford University Press, Oxford.

Orser, C. (1996). A Historical Archaeology of the Modern World. Plenum, New York.

Orwell, G. (1937). The Road to Wigan Pier. Gollancz, London.

Page, A. (1976). State intervention in the inter-war period: the Special Areas Acts 1934-37. British Journal of Law and Society 3(2): 175-203.

Patel, K. (2016). The New Deal: A Global History. Princeton University Press, Princeton, NJ.

Petts, D., Armstrong, K., and O’Donnell, R. (2018). "Heartbreak Hill," East Cleveland: Report on NonDestructive Archaeological Survey. Unpublished report, in authors' possession.

Potter, P. (1999). Historical archaeology and identity in the modern world. In: Leone, M. and Potter, P. (eds.), Historical Archaeologies of the Capitalism. Kluwer, New York, pp. 51-59.

Purser, M. (1999). Ex Occidente Lux?: an archaeology of later capitalism in the nineteenth-century West. In Leone, M. and Potter, P. (eds.), Historical Archaeologies of Capitalism. Kluwer, New York, pp. 115-141.

Rendle, E. (2003). Social and economic changes in forestry in the inter-war years. Scottish Woodland History Discussion Group Notes 8: 30-31.

Saitta, D. (2007). The Archaeology of Collective Action. University Press of Florida, Gainesville.

Sill, M. (1982). East Durham: Mining Colonisation and the Genesis of the Colliery Landscape, 17701851. Doctoral dissertation, Durham University, Durham.

Smith, M. (2001). The archaeology of a "destroyed" site: surface survey and historical documents at the Civilian Conservation Corps Camp, Bandelier National Monument, New Mexico. Historical Archaeology 35(2): 31-40.

Smith, M. (2014). A Concise History of the New Deal. Cambridge University Press, Cambridge.

Special Areas Commission. (1935). Report of the Interdepartmental Committee on Special Areas. His Majesty's Stationery Office, London.

Special Areas Commission. (1936). Report of the Interdepartmental Committee on Special Areas. His Majesty's Stationery Office, London.

Special Areas Commission. (1937). Report of the Commissioner of Special Areas in England and Wales for the Year Ended 30th September 1937. His Majesty's Stationery Office, London.

Special Areas Commission. (1938). Report of the Commissioner of Special Areas in England and Wales for the Year Ended 30th September 1938. His Majesty's Stationery Office, London.

Stamp, D. and Temple, A. (1934). The Land of Britain: The Report of the Land Utilisation Survey of Britain. Pt. 47, County Durham. Geographical Publications, London.

Stamp. D and Temple, A. (1941). The Land of Britain: The Report of the Land Utilisation Survey of Britain. Pt. 47, County Durham. Longmans, London.

Stevenson, J. and Cook, C. (1977). The Slump: Britain in the Great Depression. Quartet, London.

Special Areas (Development and Improvement) Act 1934. His Majesty's Stationery Office, London.

Special Areas (Amendment) Act 1937. His Majesty's Stationery Office, London.

Stewart, H., Jungkind, K., and Losey, R. (2020). Life on the fence line: early 20th-century life in Ross Acreage. Archaeological Dialogues 27(1): 57-77.

Tarlow, S. (2002). Excavating utopia: why archaeologists should study "Ideal" communities of the nineteenth century. International Journal of Historical Archaeology 6(4): 299-323.

Teesside Record Office (TRO). (n.d.). Exchange House, Exchange Square, Middlesbrough. 
Temple, A. (1940). The Derelict Villages of Durham County. Doctoral dissertation, Durham University, Durham.

Todd, N. (1986). Roses and Revolutionists: The Story of the Clousden Hill Free Communist and Co-operative Colony, 1894-1902. People's Publications, London.

Tuck. J. (2011). A Beer Party and Watermelon: The Archaeology of Community and Resistance at CCC Camp Zigzag, Company 928, Zigzag, Oregon, 1933-1942. Master's thesis, Portland State University, Portland, OR.

Vaggs, V. (2012). The Swarland Settlement, 1934-1947. Tyne to Tweed 66: 48-49.

Vall, N. (2004). Cultural improvers in North-East England, 1920-1960: "Polishing the Pitmen." Northern History 41(1): 163-180.

Wade-Martins, S. (2006). Smallholdings in Norfolk, 1890-1950: a social and farming experiment. Agricultural History Review 54: 305-330.

Wolf, E. (1999). Envisioning Power: Ideologies of Dominance and Crisis. University of California Press, Berkeley.

Wurst, L. (2015). The historical archaeology of capitalist dispossession. Capital and Class 39(1): 33-49.

Wurst, L. and Ridarsky, C. L.(2014). The second time as farce: archaeological reflections on the New New Deal. International Journal Historical Archaeology 18: 224-241.

Zweiniger-Bargielowska, I. (2010). Managing the Body: Beauty, Health, and Fitness in Britain, 1880-1939. Oxford University Press, Oxford.

Publisher's Note Springer Nature remains neutral with regard to jurisdictional claims in published maps and institutional affiliations. 